\title{
Effect of an Accompanying Midwife on Maternal Resilience and Preferred Route of Delivery in Pregnant Women
}

\author{
Anahita Khodabakhshi-koolaee*1, Fariba Rooshani Koosha², Leili Mosalanejad ${ }^{3}$
}

1. Department of Psychology and Education, Faculty of Humanities, Khatam University, Tehran, Iran

2. Department of Counseling, Faculty of Human Sciences, Islamic Azad University, Central Tehran Branch, Tehran, Iran

3. Non-Communicable Diseases Research Center, Jahrom University of Medical Sciences, Jahrom, Iran

\begin{abstract}
Background and objectives: Pregnancy is one of the most important and stressful periods of women's lives. Recent studies have indicated an increasing trend in caesarean section rates. Although women are becoming more impatient and less resilient about vaginal delivery, raising awareness on stress management and resilience increases women's readiness for the important task of motherhood. The purpose of this study was to investigate effect of an accompanying midwife on maternal resilience and preferred method of delivery in pregnant women.

Methods: This cross-sectional, descriptive-analytical study was performed on pregnant women who were in the final month of pregnancy and referred to the Khatam-al-Anbia and Baghiyyatollah al-Azam hospitals in Tehran (Iran) for periodic examinations in 2018. Overall, 150 pregnant women (75 with an accompanying midwife and 75 without an accompanying midwife) were selected using simple random sampling. The Connor-Davidson Resilience Scale was used to assess maternal resilience. In addition, the delivery preference (natural childbirth or cesarean section) was determined in the scale. Data were analyzed in SPSS 16 using descriptive statistics and inferential statistics at significance level of 0.05 .

Results: Pregnant women with an accompanying midwife had a significantly higher mean resilience score than those without an accompanying midwife $(\mathrm{P}=0.002)$. Moreover, the resilience score had a significant impact on subjects' preferred route of delivery $(\mathrm{P}<0.01)$.

Conclusion: The findings of this study show that pregnant women accompanied by a midwife during pregnancy have better resilience and tendency towards vaginal delivery.
\end{abstract}

Keywords: Resilience; accompanying midwife; vaginal delivery; caesarean section

\section{$\begin{array}{lll}\text { Received: 2019/11/13 } & \text { Revised:2019/11/28 } & \text { Published:2019/12/15 }\end{array}$}

*Correspondence: Anahita Khodabakhshi-koolaee, Department of Psychology and Education, Faculty of Humanities, Khatam University, Tehran, Iran

Tel: +98-2189174119

Email: a.khodabakhshid@khatam.ac.ir 


\section{INTRODUCTION}

Preventing maternal and perinatal mortality, which occur mostly during and immediately after delivery, is one of the fundamentals of social justice (1). Pregnancy and childbirth are life-changing and evolutionary events that can be stressful for women and their families (2). Maternal factors during pregnancy, such as working, resting and nutrition as well as communication and stress-coping abilities form part of the mother's lifestyle during pregnancy $(3,4)$. Although childbirth is a normal physiologic process, it can be associated with severe pain, uncertainty and failure, resulting in a sense of loneliness and vulnerability (5). Studies show that stress during pregnancy is associated with preterm birth, low birth weight, hypertension, toxemia, depression and childhood allergic diseases (6). One way to deal with these stresses is resilience, a normal concept and construct of interest in positive psychology that refers to successful adaptation despite challenges and threats (7). In addition, resilience is the ability to overcome adversity, trauma, tragedy, threats or significant stressful events $(8,9)$. Resilient individuals have strong personalities and mental and physical health compared to those who are intolerant and impatient when facing stressful events (9, $10)$. Fear of vaginal delivery is a common problem among pregnant women that often leads to request for cesarean section. It is estimated that about $5-20 \%$ of pregnant women fear childbirth (11) while $9-13 \%$ of them experience debilitating and extreme fear, which is associated with an increased rate of cesarean section $(12,13)$. Fear of childbirth leads to anxiety and will have a negative impact on maternal and neonatal outcomes (14). In this regard, the World Health Organization has addressed the importance of maternal support for reducing fear and stress of mothers during labor and delivery (15). Continuous midwifery support includes emotional support (continuous presence, reassurance and encouragement), physical support (decreased thirst, hunger and pain), providing an insight into the process of childbirth and its management, respecting the mother in the decision making process and helping mothers establish communication with other caregivers (16).

Numerous studies have also demonstrated the positive effect of having a midwife during labor and delivery (17-21). According to previous studies, a cascade of chemical substances is produced in response to stress during labor, which calms the mother and forms her future behavior towards her child and other women $(22,23)$. In addition, a study reported that midwives' continuous support during delivery reduces length of delivery, amount of stress, the need for oxytocin administration and increases childbirth satisfaction (28).

Given the importance of communication between midwives and pregnant women, the aim of this study was to investigate effects of accompanying midwives on maternal resilience and preffered method of delivery.

\section{MATERIALS AND METHODS}

This applied descriptive-analytical study was carried out in 2018 on pregnant women who were in the final month of pregnancy and referred to the Khatam-al-Anbia and Baghiyyatollah al-Azam hospitals in Tehran (Iran) for periodic examinations. Overall, 150 pregnant women (75 with an accompanying midwife and 75 without an accompanying midwife) were selected using simple random sampling. Exclusion criteria included a previous history of postpartum depression, inherited blood and genetic disorders and participation in another support program. The Connor-Davidson Resilience Scale (2003) was used to assess resilience (1). The questionnaire consists of 25 items that are scored on a five point Likert scale ranging from 0-4: not true at all (0), rarely true (1), sometimes true (2), often true (3), and almost always true (4). According to results of factor analysis, the scale describes the notion of personal competence, trust in personal instincts, tolerance of negative emotions, positive acceptance of change, secure relationships, control and spiritual influences. 
Journal of Clinical and Basic Research (JCBR). 2019; 3(4): P 7-12.

The cut-off point for this scale is a score of 75 , i.e. scores above 75 indicate high resilience and scores below 75 indicate low resilience. In addition, the delivery preference (natural or cesarean section) was determined in the scale.
Data were analyzed in SPSS 16 using descriptive statistics and inferential statistics at significance level of 0.05 .

\section{RESULTS}

Table 1 shows the frequency distribution of subjects based on age, length of marriage, gravidity and method of delivery.

Table 1. Frequency distribution of subjects based on gravidity, length of marriage, age and method of delivery

\begin{tabular}{|c|c|c|c|c|c|c|c|}
\hline Group & $\begin{array}{c}\text { Mean }( \pm \\
\text { SD) age }\end{array}$ & $\begin{array}{c}\text { Mean }( \pm \\
\text { SD) } \\
\text { length of } \\
\text { marriage }\end{array}$ & $\begin{array}{c}\text { Gravida } \\
\mathbf{1}\end{array}$ & $\begin{array}{c}\text { Gravida } \\
\mathbf{2}\end{array}$ & $\begin{array}{c}\text { Gravida } \\
\mathbf{3}\end{array}$ & $\begin{array}{c}\text { Vaginal } \\
\text { delivery }\end{array}$ & $\begin{array}{c}\text { Caesarean } \\
\text { section }\end{array}$ \\
\hline $\begin{array}{c}\text { With } \\
\text { accompanying } \\
\text { midwife } \\
(\mathrm{n}=75)\end{array}$ & $\begin{array}{c}28.67(3.895) \\
\text { years }\end{array}$ & $\begin{array}{c}6.0 \\
(3.259) \\
\text { years }\end{array}$ & $\begin{array}{c}35 \\
(46.7 \%)\end{array}$ & $\begin{array}{c}30 \\
(40 \%)\end{array}$ & $\begin{array}{c}10 \\
(13.3 \%)\end{array}$ & $\begin{array}{c}52 \\
(69.3 \%)\end{array}$ & $23(30.7 \%)$ \\
\hline $\begin{array}{c}\text { Without } \\
\text { accompanying } \\
\text { midwife } \\
(\mathrm{n}=75)\end{array}$ & $\begin{array}{c}27.96(3.978) \\
\text { years }\end{array}$ & $\begin{array}{c}6.36 \\
(3.364) \\
\text { years }\end{array}$ & $\begin{array}{c}33 \\
(44 \%)\end{array}$ & $\begin{array}{c}31 \\
(41.3 \%)\end{array}$ & $\begin{array}{c}11 \\
(14.7 \%)\end{array}$ & $\begin{array}{c}18 \\
(24 \%)\end{array}$ & $57(76 \%)$ \\
\hline
\end{tabular}

SD: standard deviation

Table 2 summarizes the mean score of each group of subjects in components of resilience.

Table 2. Comparison of mean scores of resiliency components between the two study groups

\begin{tabular}{|c|c|c|c|c|c|c|c|}
\hline \multirow{2}{*}{$\begin{array}{c}\text { Dependent } \\
\text { variable }\end{array}$} & \multicolumn{2}{|c|}{$\begin{array}{c}\text { Without } \\
\text { accompanying } \\
\text { midwife }\end{array}$} & \multicolumn{2}{|c|}{$\begin{array}{l}\text { With accompanying } \\
\text { midwife }\end{array}$} & \multirow{2}{*}{$\begin{array}{l}\text { Total of } \\
\text { Squares }\end{array}$} & \multirow{2}{*}{$\mathbf{F}$} & \multirow{2}{*}{ P-value } \\
\hline & Mean & $\begin{array}{l}\text { Standard } \\
\text { deviation }\end{array}$ & Mean & $\begin{array}{l}\text { Standard } \\
\text { deviation }\end{array}$ & & & \\
\hline $\begin{array}{c}\text { Notion of } \\
\text { personal } \\
\text { competence }\end{array}$ & 4.2 & 39.38 & 2.3 & 32.28 & 612.113 & 9.698 & 0.002 \\
\hline $\begin{array}{c}\text { Tolerance } \\
\text { of negative } \\
\text { emotions }\end{array}$ & 3.2 & 28.45 & 3.4 & 24.35 & 891.988 & 14.977 & 0.001 \\
\hline $\begin{array}{c}\text { Positive } \\
\text { acceptance } \\
\text { of change } \\
\text { and secure } \\
\text { relationship } \\
\text { s }\end{array}$ & 2.6 & 17.29 & 2.5 & 18.25 & 18.343 & 1.156 & 0.284 \\
\hline Control & 2.6 & 20.02 & 3.4 & 21.88 & 19.165 & 1.696 & 0.195 \\
\hline $\begin{array}{c}\text { Spiritual } \\
\text { influences }\end{array}$ & 3.1 & 20.24 & 2.9 & 19.89 & 0.882 & 0.322 & 0.631 \\
\hline
\end{tabular}

After verifying the equality of variance using Levene's test, independent t-test was used to compare the mean resilience score between the two groups. Based on the results, the mean resilience score in women with an accompanying midwife $(69.33 \pm 15.15)$ was significantly higher than in those without an 
Journal of Clinical and Basic Research (JCBR). 2019; 3(4): P 7-12.

accompanying midwife $\quad(61.71 \pm 13.89)$ $(\mathrm{P}=0.002)$.

As shown in table 3, more than $90 \%$ of pregnant women with a low resilience score preferred caesarean section, while more than $50 \%$ of pregnant women with a high resilience score preferred vaginal delivery.

Table 3. Comparison of delivery preference between women with and without an accompanying midwife based on the resilience score

\begin{tabular}{|c|c|c|c|c|c|c|}
\hline \multicolumn{2}{|c|}{ Variable } & \multicolumn{2}{|c|}{ Type of delivery } & \multirow[b]{2}{*}{ Total } & $\chi^{2}$ & \multirow[b]{2}{*}{ Significant } \\
\hline $\begin{array}{l}\text { Resilience in } \\
\text { women }\end{array}$ & & $\begin{array}{l}\text { Vaginal } \\
\text { delivery }\end{array}$ & $\begin{array}{c}\text { Ceasarean } \\
\text { section }\end{array}$ & & \multirow{3}{*}{17.942} & \\
\hline without & Low & $4(8.3 \%)$ & $44(91.7 \%)$ & $48(100 \%)$ & & \multirow[b]{2}{*}{0.001} \\
\hline $\begin{array}{c}\text { accompanying } \\
\text { midwife }\end{array}$ & High & $14(51.9 \%)$ & $13(48.1 \%)$ & $27(100 \%)$ & & \\
\hline \multirow{5}{*}{$\begin{array}{l}\text { Resilience in } \\
\text { women with } \\
\text { accompanying } \\
\text { midwife }\end{array}$} & Total & $18(24 \%)$ & $75(76 \%)$ & $75(100 \%)$ & \multirow{5}{*}{52.619} & \multirow{5}{*}{0.001} \\
\hline & Low & $6(20.7 \%)$ & $23(79.3 \%)$ & $29(100 \%)$ & & \\
\hline & High & $64(100 \%)$ & 0 & $46(100 \%)$ & & \\
\hline & Total & $3(69.3 \%)$ & $23(30.7 \%)$ & $75(100 \%)$ & & \\
\hline & & & & & & \\
\hline
\end{tabular}

\section{DISCUSSION}

Based on our results, maternal resilience differed significantly between pregnant women with and without an accompanying midwife. In this regard, Lee (2015) stated that trusting midwives allows pregnant women to overcome childbirth-associated worries, sorrows and pain (29). Our findings are in line with findings of two previous studies $(30,31)$. An accompanying midwife acts as an important and reliable source of support in stressful situations, which can increase the resilience of pregnant women. A midwife's contemplation and attention to duties can also reflect on pregnant women who are impatient and not resilient, which further clarifies the benefits of an accompanying midwife (3234). Our results also showed that having an accompanying midwife could influence delivery preference in pregnant women. This finding is consistent with findings of studies by Khodabakhshi Koolaee et al. (6) and

Ahmadi et al. (35). AktaŞ et al. (2016) reported that programs such as midwifemother empathy training, can lead to long- term behavioral changes and improve midwives' empathy skills, thus promoting vaginal birth as well as maternal and neonatal health (36). Furthermore, highly resilient people can seek help depending on the situation, and naturally, after receiving appropriate responses, they can reach a more suitable decision. In fact, pregnant women without an accompanying midwife are less resilient and aware of their situation and therefore have an increased tendency towards caesarean section.

In future studies, it is suggested to assess the impact of other variables such as education level, socioeconomic status, marital satisfaction and stress coping styles on resilience and delivery preference in pregnant women.

\section{CONCLUSION}

The findings of this study show that pregnant women accompanied by a midwife during pregnancy have better resilience and tendency towards vaginal delivery.

\section{ACKNOWLEDGMENTS}

This article has been derived from a thesis supported by the Islamic Azad University, North Tehran Branch (ethics approval code: 
950296002). The authors are grateful to all subjects for their cooperation.

\section{DECLARATIONS \\ Funding}

Not applicable.

\section{Ethics approvals and consent to participate}

The study has been approved by the ethics committee of the Islamic Azad University, North Tehran Branch, Tehran, Iran (approval code: 950296002).

\section{Conflict of interest}

The authors declare that there is no conflict of interest regarding the publication of this article.

\section{REFERENCES}

1. Shahidi Sh, Shirafkan S. Psychology and Spirituality, Tehran: Growth Publishing;2004. (Persian).

2. heidari $\mathrm{T}$, ziaei $\mathrm{S}$, ahmadi $\mathrm{F}$, mohammadi $\mathrm{E}$. Body and spirit promoting during pregnancy: A content analysis study. Sci J Hamadan Nurs Midwifery Fac. 2014; 22 (1) :5-14. (Persian).

3. Sehati Shafaie F, Sheybani F. Lifestyle and its relationship with pregnancy outcomes in pregnant women referred to educational hospitals in Tabriz. Iranian Journal of Obstetrics, Gynecology and Infertility. 2015;17(131):13-19. (Persian).

4. Stager L. Supporting women during labor and birth. Midwifery Today Int Midwife .2009; 92:125 .

5. Umeora J, Ugochukwu O, Ukkaegbe CI, Eze JN, Masekoameng AK. Spousal companionship in labor in an urban facility in South East Nigeria. Anatol J Obstet Gynecol .2011; 2:1-5.

6. Khodabakhshi Koolaee A, Heidari S, Khoshkonesh A, Heidari M. Relationship between Spiritual Intelligence with Resilience to Stress and the Preference of Delivery Method among Pregnant Women. Iranian Journal of Obstetrics, Gynecology and Infertility. 2013; 16(58): 8-15. (Persian).
7. Hanewald R. Reviewing the literature on "AtRisk" and resilient children and young people, Australian Journal of Teacher Education .2011; 36(2). [DOI:10.14221/ajte.2011v36n2.2]

8. Alizadeh H. Cognitive resilience (psychological well-being and behavioral disorders), Tehran: Arasbaran publication; 2013. (Persian).

9. Agaibi, C. E, \& Wilson, J. P. Trauma, PTSD, and resilience: A review Of the Literature. Trauma, Violence, \& Abuse.2005; 6(3), PP: 195216. [DOI:10.1177/1524838005277438]

10. Mosala Nejad L, Khodabakhshi koolaie A, Shoyukh F. The Effect of Spiritual Therapy on Pregnancy rate, Journal of Psychology of Behavior. 2012; 6(1): 78-81. (Persian).

11. Spice K, Jones SL, Hadjistavropoulos HD, Kowalyk K, Stewart SH. Prenatal fear of childbirthand anxiety sensitivity. J Psychosom Obstet Gynecol Sep. 2009;30(3):168-74. [DOI:10.1080/01674820902950538]

12. Alipour Z, Lamian M, Hajizadeh A, Vafaie M. The Relationship between Selected Anxiety and Maternal Fear in Pregnant Women, Journal of Women's Nursing. 2011; 16(2): 169-73. (Persian).

13. Nasiri F, Sharifi Sh. Relationship between fear of childbirth and personality type in pregnant women, Women , Obstetrics and Gynecology journal. 2013; 16(66): 18-25. (Persian).

14. Alderdice F, Lynn F. Factor structure of the Prenatal distress questionnaire. Midwifery .2011; 27(4):553-9. [DOI:10.1016/j.midw.2010.05.003]

15. Bruggemann OM, Parpinelli MA, Osis MJ, Cecatti JG, Neto AS. Support to woman by a companion of her choice during childbirth: a randomized controlled trial. Reprod Health .2007; 4(1):5. [DOI:10.1186/1742-4755-4-5]

16. Lundgren I. Swedish women's experiences of doula support during childbirth. Midwifery .2010; 26(2):173-80. [DOI:10.1016/j.midw.2008.05.002]

17. Klaus MH, Kennell JH. The doula: an essential ingredient of childbirth rediscovered. Acta Paediatr 1997; 86(10):1034-6. [DOI:10.1111/j.1651-2227.1997.tb14800.x] 
18. Zhang J, Bernasko JW, Leybovich E, Fahs M, Hatch MC. Continuous labor support from labor attendant for primiparous women: a metaanalysis. Obstet Gynecol .1996; 88(4 Pt 2):73944. [DOI:10.1016/0029-7844(96)00232-3]

19. Sosa R, Kennell J, Klaus M, Robertson S, Urrutia J. The effect of a supportive companion on perinatal problems, length of labor, and mother-infant interaction. N Engl J Med .1980; 303(11):597-600.

[DOI:10.1056/NEJM198009113031101]

20. Javad NM, Afshari P, Montazeri S, Latifi SM. The effect of continuous labor support by accompanying person during labor process. Jundishapur Sci Med J .2008; 7(1):32-8. (Persian).

21. Samieizadeh Toosi T, Sereshti M, Dashipur AR, Mohammadinia N, Arzani A. The effect of supportive companionship on length of labor and desire to breastfeed in primiparous women. $\mathbf{J}$ Urmia Nurs Midwifery Facul .2011; 9(4):262-9. (Persian).

22. Pascali-bonaro D, Kroeger M. Continuous female companionship during childbirth: a crucial resource in times of stress or calm. J Midwifery Womens Health .2004; 49(4 Suppl 1):19-27. [DOI:10.1016/j.jmwh.2004.04.017]

23. Simkin P, Bolding A. Update on nonpharmacologic approaches to relieve labor pain and prevent suffering. J Midwifery Womens Health .2004; 49(6):489-504. [DOI:10.1016/j.jmwh.2004.07.007]

24. Lowe NK. The nature of labor pain. Am J Obstet Gynecol .2002; 186:S16-24. [DOI:10.1067/mob.2002.121427]

25. Lundgren I, Berg M. Central concepts in the midwife-woman relationship. Scan J Caring Sci. 2007; 21(2):220-8. [DOI:10.1111/j.14716712.2007.00460.x]

26. Holte A. Professional communication skills. Scan J Prim Health Care.2005; 8(3):131-2. [DOI:10.3109/02813439008994945]

27. Beygi M, Bahadoran P. Relationship between the stress of labor and the birth weight of newborns, Journal of Nursing. 2008; 5(26): 9-25. (Persian).
28. Lundgren I. Swedish women's experiences of doula support during childbirth. Midwifery. 2010; 26(2):173-80. [DOI:10.1016/j.midw.2008.05.002]

29. Lee T. Psychosocial distress and wellbeing: Resilience among indigenous Mayan women in Western Guatemala (Doctoral dissertation, McGill University);2015.

30. Khavandizadeh Aghdam S. The effect of the continuous labor support from a supportive companion on the process and outcomes of labor in primigravida. J Ardabil Univ Med Sc .2006; 6(4):368-73. (Persian)

31. Ahmadi Z. Evaluation of the effect of continous midwifery support on pain intensity in labor and delivery. J Rafsenjan Univ Med Sci .2010; 9(4):293-304. (Persian).

32. naghizadeh S, Sehati Shafaie F,Borzanje Atri Sh, Ebrahimi H, Ebrahimpour M. 2012; 15(38): 24-31. (Persian).

33. Attarha M, Keshavarz Z, Bakhtiari M \& Jamilian $M$. The outcome of midwife-mother relationship in delivery room: a qualitative content analysis Health. 2016; 8(04), 336. (Persian). [DOI:10.4236/health.2016.84035]

34. Burroughs A. Maternity nursing, . 7 th ed. Philadelphia: W.B. Saunders Company; 1997. P.: 3.

35. Ahmadi Y, Sharifi far T, Pishgui A, Teymuri F, Hosseini M, Yari M. 2016;3(4): 242-248. (Persian).

36. AktaŞ S, Pasinlioğlu T \& Çalik K. The Effect of Empathy Traning Given to Midwives on Mothers'Birth Perceptions and Their Satisfaction with Midwives. Life Sciences.2016; 11(3): 1-10. [DOI:10.12739/NWSA.2016.11.4.4B0007] 